University at Buffalo School of Law

Digital Commons @ University at Buffalo School of Law

Journal Articles

Faculty Scholarship

$1-20-2017$

\title{
The International Criminal Court: Promise and Politics
}

Makau wa Mutua

University at Buffalo School of Law

Follow this and additional works at: https://digitalcommons.law.buffalo.edu/journal_articles

Part of the Criminal Law Commons, and the International Law Commons

\section{Recommended Citation}

Makau w. Mutua, The International Criminal Court: Promise and Politics, 109 Proceedings of the ASIL Ann. Meeting 269 (2017).

Available at: https://digitalcommons.law.buffalo.edu/journal_articles/644

\section{C) ${ }_{\text {COPYRIGHT }}^{\text {N }}$}

This Article is brought to you for free and open access by the Faculty Scholarship at Digital Commons @ University at Buffalo School of Law. It has been accepted for inclusion in Journal Articles by an authorized administrator of Digital Commons @ University at Buffalo School of Law. For more information, please contact lawscholar@buffalo.edu. 


\title{
THE NATIONAL IMPACT OF INTERNATIONAL CRIMINAL LAW
}

This panel was convened at 1:00 p.m., Friday, April 10, by its moderator Alexander K. A. Greenawalt of Pace Law School, who introduced the panelists: Elizabeth Evenson of Human Rights Watch; Nina H.B. Jørgensen of the Chinese University of Hong Kong Faculty of Law; Makau Mutua of SUNY Buffalo Law School; and Sarah Nouwen of the University of Cambridge.*

\section{The International Criminal Court: Promise and Politics}

\author{
By Makau Mutua ${ }^{\dagger}$
}

\section{INTRODUCTION}

The International Criminal Court (ICC or Court) is an institution born of necessity after a long and arduous process of many false starts. The struggle to establish a permanent international criminal tribunal stretches back to Nuremberg. ${ }^{1}$ The dream, which was especially poignant for the international criminal law community, for a permanent international criminal tribunal was realized with the adoption in 1998 of the Rome Statute of the International Criminal Court. ${ }^{2}$ The treaty entered into force in 2002. Those were heady days for advocates and scholars concerned with curtailing impunity. No one was more ecstatic about the realization of the ICC than civil society actors across the globe, and particularly in Africa, where impunity has been an endemic problem. ${ }^{3}$ Victims who had never received justice at home saw an opportunity for vindication abroad. This optimism in the ICC was partially driven by the successes, however mixed, of two prior ad hoc international criminal tribunals-the International Criminal Tribunal for Rwanda and the International Criminal Tribunal for the Former Yugoslavia.

Advocates were hopeful that the ICC would learn valuable lessons from the mistakes of the ad hoc tribunals and become the altar of international justice for states that were unable, or unwilling, to hold accountable the most egregious offenders. However, there is a growing narrative that the ICC has been more of a heartbreak for victims-and an impotent protagonist for offenders - than its supporters had imagined. More than a decade since it went live, the ICC has badly stumbled while its beneficial effects to municipal law have been minimal, if any. The institution that was supposed to drastically curb the culture of impunity across the globe, and open a new page for the rule of law, is today more a symbol of what could have been. The concept of the ICC remains valid, but the results point to an institution that is under siege. What went wrong? Can the ICC be salvaged, or has it been mortally wounded by its own mistakes and the institutional defects inherent in it? I offer several reasons why the ICC has failed to lead a new era in the domestication of the norms and processes of international criminal law. The international criminal law and human rights communities are

\footnotetext{
${ }^{*}$ Mr. Greenawalt, Ms. Evenson, and Ms. Nouwen did not contribute remarks for the Proceedings.

†UNY Distinguished Professor at SUNY Buffalo Law School.

${ }^{1}$ M. Cherif Bassiouni, The Legislative History of the International Criminal Court (2005).

${ }^{2}$ Rome Statute of the International Criminal Court, UN Doc. A/CONF.183/9 (adopted July 17, 1998) [hereinafter, Rome Statute].

${ }^{3}$ Brigitte Suhr, Lubanga Sentence Vindicates Faith in ICC, AL JAZEERA (July 18, 2012), at http://www.aljazeera.com/indepth/opinion/2012/07/2012717124034534428.html.
} 
prone to narratives of optimism but blind to sins of conception. This disconnect does not augur well for the ICC. It may not be too early to think about a post-mortem of the ICC if fundamental reforms are not carried out to save the institution.

\section{FAILURE OF LEADERSHIP}

Young international institutions, especially those born with high expectations, must live up to the hype which brought them into existence. To do so, they must be seen to effectively discharge their mandates, but this requires a leadership that is able to mold the institution and build clear and purposeful objectives and structures. For the ICC, not a single office was more important than the Office of the Prosecutor (OTP). The person of the prosecutor occupies a unique office within the court. The prosecutor is the single most important individual within the system, and is the key to the effectiveness of the court and the judges. It is the prosecutor who must decide the situations that warrant investigation and prosecution. In that sense, the prosecutor exercises discretion that can ultimately determine case selection and the perception that the world has of the court. Judges are clearly important actors within the court, but they are helpless to adjudicate cases that the prosecutor has failed to investigate and litigate effectively.

With all due respect to him, Luis Moreno Ocampo, the inaugural prosecutor of the ICC, must share some of the blame for the failures of the court. He did not create a formidable institutional identity for the OTP. This would have given the judges opportunities to impress the court's foes and friends alike. He was arguably a successful champion of justice in Argentina, but Moreno Ocampo's performance at the ICC left much to be desired. His proclivity for theatrics and a showman's flair boomeranged against the court. He was so consumed with public appearances that he apparently did not pay adequate attention to his role as the founding prosecutor. By the time he left office, the ICC had virtually nothing to show for its decade of existence. The lack of effectiveness of the OTP and Moreno Ocampo's failure to engage meaningfully with states, sapped the enthusiasm that many had for the court. The long interminable delays and setbacks in the cases he pursued caused much despair among victims and advocates. ${ }^{4}$

\section{DEFECTS OF CONCEPTION}

In retrospect, the acclaim that greeted the court should have been tempered by its many structural and normative problems. First, the introduction of the UN Security Council (UNSC), a political body, into the work of the ICC, a legal body, unduly politicized it and opened it up to attacks that have weakened it to domestic audiences. ${ }^{5}$ The UNSC arrogated to itself the power to refer $^{6}$ and defer cases, ${ }^{7}$ and can do so for reasons that have nothing to do with the law or justice. The Security Council's referral of Libya to the court stands out for a number of reasons. ${ }^{8}$ The African Union's (AU) mediation efforts to end the conflict were

\footnotetext{
${ }^{4}$ Ali Ezzatyar, Fending off Failure: The International Criminal Court's New Chief Prosecutor, The Moderate VoICE (June 27, 2012), at http://themoderatevoice.com/151042/fending-off-failure-the-international-criminal-courtsnew-chief-prosecutor/.

${ }^{5}$ Charles Jallow, Dapo Akande, \& Max du Plessis, Assessing the African Union's Concerns about Article 16 of the Rome Statute of the International Criminal Court, 4 AFr. J. L. STUdies 5-50 (2011).

${ }^{6}$ Rome Statute, supra note 2, art. 13(b).

${ }^{7}$ Id. at art. 16.

${ }^{8}$ ICC, "Situation in Libya", (Feb. 26, 2011), at http://www.icc-cpi.int/en_menus/icc/situations\%20and\%20cases/ situations/icc0111/Pages/situation\%20index.aspx.
} 
ignored by NATO and the UNSC. This referral has been widely condemned as an attempt to use the ICC to advance the blatant agenda of global powers to get rid of Muammar Gaddafi, an old enemy of the west. Many commentators pointed to the lightning speed of the referral as an example of the UNSC's and the ICC's racial bias against Africans. ${ }^{9}$ It does not help that all the cases before the Court are African. ${ }^{10}$

Ironically, the Security Council's inability and failure to act more forcefully on Sudan's Omar al Bashir, a sitting African head of state indicted by the ICC, has compounded the appearance of the Court's impotence. It paints a picture of a Court mired in the cauldron of politics. In November 2013, the UNSC declined to defer the Kenyan cases of Uhuru Kenyatta and William Ruto, respectively elected president and deputy president in April of that year. ${ }^{11}$ But the Assembly of States Parties (ASP) to the Rome Statute bent to the will of the AU and amended the Rules of Procedure and Evidence to accommodate indicted high officials, such as heads of state, during trial. Such officials may be excused from appearing in person for particular court sessions. ${ }^{12}$ Finally, the Kenyan cases, especially Kenyatta's, showed that a state cannot be expected to cooperate in the prosecution of a sitting head of state. With Kenyatta as head of state, Kenya refused to cooperate with the Court leading to the withdrawal of his case.

\section{Politicization of the Court}

The UNSC's intrusion into the court's work is but one of many structural and political questions hanging over its credibility. One can understand why the ASP is part of the structure of the Court, but its powers give it a large latitude to bend the court to the will of powerful states, or block of states, as has been the case with the AU. In the view of many, this amounts to the political supervision of the court in response to non-legal questions. This conflation of the politics and law at the UNSC and ASP levels denies the court the credibility it needs to lead states parties in the domestication of international criminal legal norms. In fact, it sets the opposite example-that power, geopolitics, and might can trump law. This is the very definition of impunity. So, in a paradox, the ICC's structural deficits help entrench rather than combat impunity. It is true that the ICC is a creature of political compromise, which is a necessity for intergovernmental organizations, but it cannot be taken seriously if it is failing at its core mandate-holding the most powerful accountable for heinous offenses.

President Uhuru Kenyatta was credibly alleged to have orchestrated and funded the 2008 post-election violence in which 1,300 people were killed, 600,000 displaced, and thousands maimed, raped, and pillaged. ${ }^{13}$ Yet, if one is to believe the ICC Prosecutor, Kenyatta was able to go scot-free by killing, bribing, and intimidating witnesses, and coercing them to recant their sworn testimonies. The ICC's witness protection program is poorly conceived and executed. The Kenyan cases demonstrated that indictees could interfere with, and even

\footnotetext{
${ }^{9}$ ICC Forum, Is the International Criminal Court Targeting African Inappropriately (Mar. 2013-Jan. 2014), at http://iccforum.com/africa.

${ }^{10}$ Makau Mutua, The International Criminal Court in Africa: Challenges and Opportunities, Norwegian Peace Building Centre (NOREF) (Sept. 2010), at http://www.peacebuilding.no/Themes/Peace-processes-and-mediation/ publications/The-International-Criminal-Court-in-Africa-challenges-and-opportunities/(language)/eng-US.

${ }^{11}$ Bid to Defer International Court Criminal Cases of Kenyan Leaders Fails, AllAfrica.com (Nov. 15, 2013), at http://allafrica.com/stories/201311151551.html.

${ }^{12}$ ICC, Rules of Procedure and Evidence, Rule 134, at http://www.icc-cpi.int/en_menus/icc/legal\%20texts\%20and$\%$ 20tools/official\%20journal/Pages/rules\%20of\%20procedure\%20and\%20 vidence.aspx.

${ }^{13}$ Kenya Failing Post-Election Violence Victims, Says Amnesty, The Guardian (July 15, 2014), at http:// www.theguardian.com/global-development/2014/jul/15/kenya-post-election-violence-amnesty-international.
} 
kill and disappear witnesses with impunity. As the OTP pre-trial brief stated, Kenyatta literally cleaned up the evidence. ${ }^{14}$ And yet the Court and the ASP have been powerless to hold Kenya accountable. The prosecutor had no choice but to withdraw the case in the face of blatant violations of the Rome Statute, and Kenya's own laws, including the Kenyan Constitution. The Kenyan cases demonstrate that a state with some international clout-a strategic economy with a geopolitical nexus, a collaborator on the war on terror, and wealthy indictees, can prevail against the ICC by hook, or crook. There is no other way to describe how and why Kenyatta managed to defeat justice at the ICC. It was not because of the cynical narrative by the African Union that the ICC has been "race hunting" Africans. Otherwise how would one explain the AU's support for the ICC in Cote d'Ivoire, Mali, Central African Republic, the DRC, and Uganda, which has referred Joseph Kony of the Lord's Resistance Army and his lieutenants to the ICC ${ }^{15}$ These acts of politicization have robbed the ICC of the power of demonstration-to show states how impunity can be combated at home. The ICC is an incomplete institution because powerful, global hegemons like the United States and new powers like China and India, and old ones like Russia, have spurned the Court. These body blows empower cynics to delegitimize the ICC among pliable domestic actors.

\section{CONCLUSION}

International law does not, and is not meant to, displace domestic law. This is true in all areas of international law, but it is even truer in human rights and related fields where the state is the obligor to those who live under its roof. States must be willing to submit themselves to constitutional norms of behavior that safeguard human rights. That is the only way international law plays the role described by Marti Koskenniemi as the "gentle civiler of nations." 16 Intergovernmental organizations and other multilateral agencies can bring the hammer down against certain states, but in the end, violator states must undertake to respect certain values. Where the intergovernmental organization lacks moral standing, or is viewed as compromised by big power politics, it loses its ability to inspire and engender domestic respect, including the domestication of its norms. This may soon become the fate of the ICC, unless there are some drastic changes. In Kenya, for example, the International Crimes Act, which domesticated the Rome Statute, is under threat of repeal by the detractors of the ICC. The law has become more of a formality than legal reality because there is no political will to invoke it in the courts. The police force, the country's attorney general, and the director of prosecutions are unable, and unwilling, to enforce the law because they are beholden to cartels of impunity. That is why I conclude where I started-the ICC failures at The Hague have sabotaged attempts to domesticate its norms and values among states parties. It is worrying that the ICC may be abandoned by victims who increasingly see hope for justice at The Hague as a phantom of the imagination. My hope is that Fatou Bensouda, the experienced jurist who succeeded Moreno Ocampo, will act to correct some of the more avoidable problems. We may start contemplating a post-mortem of the ICC unless its structural and conceptual deficits are addressed.

\footnotetext{
${ }^{14}$ Prosecutor v. Uhuru Muigai Kenyatta, Case No. ICC-01/09-02/11, Decision on the Withdrawal of Charges Against Mr Kenyatta (Mar. 13, 2015), at http://www.icc-cpi.int/iccdocs/doc/doc1936247.pdf.

${ }^{15}$ Vincent Nmehielle, Africa and the Future of International Criminal Justice (2012).

${ }^{16}$ Marti Koskenniemi, The Gentle Civilizer of Nations: The Rise and Fall of International Law 1870-1960 (2004).
} 